\title{
EFFECT OF INORGANIC FERTILIZER APPLICATION ON GROWTH AND YIELD OF THEVETIA PERUVIANA (PERS) SCHUM. (YELLOW OLEANDER) IN THE SOUTHERN GUINEA SAVANNAH OF NIGERIA \\ ${ }^{1}$ Aboyeji, C. M. and ${ }^{2}$ Babalola, F. D. \\ 1Department of Agronomy Department, University of Ilorin, llorin, Nigeria \\ 2Department of Forest Resources Management, University of llorin, Nigeria \\ Corresponding author: chrismuyiwa@yahoo.com
}

\begin{abstract}
Growth and yield parameters of Thevetia peruviana (Pers) Schum. were evaluated under inorganic fertilizer in 2009, 2010 and 2011 rainy seasons at the Research farms of the Biofuel and Alternate Renewable Energy Ltd, Edidi, Kwara State in the southern Guinea savannah of Nigeria. The objective of the study was to determine the influence of different rates of $N$ and $P$ fertilizers on the vegetative growth and yield of T. peruviana. The experiment was laid out in a RCBD in a factorial arrangement with three replications. The factors includes: 3 levels of $N(0,30$ and $60 \mathrm{~kg}$ $\left.\mathrm{ha}^{-1}\right)$ and 3 levels of $P\left(0,30\right.$ and $\left.60 \mathrm{~kg} \mathrm{ha}^{-1}\right)$ which were combined factorially. The results indicated that application of $0 \mathrm{~kg} \mathrm{~N} \mathrm{ha}^{-1}$ and $30 \mathrm{~kg} \mathrm{P}_{2} \mathrm{O}_{5} \mathrm{ha}^{-1}$ resulted in increased plant height, number of primary branches, stem girth, number and weight of harvested seeds. It was also observed that application of $60 \mathrm{~N} \mathrm{~kg} \mathrm{ha-1}$ and $0 \mathrm{~kg} \mathrm{P}_{2} \mathrm{O}_{5} \mathrm{~kg} \mathrm{ha}^{-1}$ delayed number of days to both first and $50 \%$ flowering. Based on the result of this study it is recommended to apply only $30 \mathrm{~kg}$ $\mathrm{P}_{2} \mathrm{O}_{5}$ ha-1 $^{-1}$ because the native nitrogen in the soil was enough for both the growth and yield performance of T. peruviana in the study area.
\end{abstract}

Keywords: - Thevetia periviana, Growth, Yield, Nitrogen and Phosphorus fertilizers.

\section{INTRODUCTION}

Thevetia peruviana (Pers) Schum. is native to tropical America; especially Mexico, Brazil and West Indies and has naturalized in tropical regions worldwide (Daniel, 1937). It is commonly known as Yellow oleander (nerium), Lucky nut, Be-still tree, gum bush, bush milk, exile tree in India, and Olomi-ojo by the Yorubas in Nigeria. Its fruit is green in colour when unripe and changes from brown to black as it ripens. It encases a large dicotyledonous seed which is capsule-like, hard, angled, up to 1 inch in diameter and may remain viable after one year of proper storage. In its native countries, the plant has been known for more than 2000 years (Balusamy and Manrappan, 2007). In the wild the plant flowers after about one and half years and blooms thrice a year (Balusamy and Manrappan, 2007). T. peruviana produces between 400-800 fruits yearly depending on the rainfall and plant age (Ibiyemi et al., 2002). The number of kernels per fruit and the oil yield varied significantly among geographical locations. The plant has annual seed yield of 52.5 tonnes ha-1 $^{-1}$ at maturity (i.e. after 4 years old) and about 1,750 litres of oil can be obtained from an hectare of waste land where the plant is growing (Balusamy and Manrappan, 2007). 
In the last ten years, chemists have revealed the potentials and prospects of some plants (Jatropha curcas and T. peruviana) which are not food crops and do not compete with the human food chain and they are viable sources of bio-oils. Recent research by lbiyemi et al. (1995)

revealed that $T$. peruviana has superior oils in terms of quality and quantity than $\mathrm{J}$. Curcas. The seed contains $60-65 \%$ oil and the cake comprise of $30-37 \%$ protein. Despite the fact that there is high level of oil and protein in the seed, it remains non - edible because of the presence of cardiac glycoside (toxins). According to Atteh et al. (1995) and Oluwaniyi et al. (2007), the crude protein content of the defatted seed ranges from $42.79-47.50 / 100 \mathrm{~g}$ of the seed cake while crude lipid ranges from 4.40 to $4.80 / 100 \mathrm{~g}$.

It is obvious that the world has shifted sourcing protein for animal diets and oils for industrial raw material to oil seeds. Notable among the oil seeds are J. curcas, J. gosipifolia, neem seed, and rape seed. Usman et al. (2009) therefore concluded that the plant can thus be used as an alternative protein source in animal feed formulation. If well processed, it would reduce competition between man and livestock for the conventional sources of proteins. The oil could also be useful in the production of oleochemicals such as liquid soap, shampoos, alkyd resin, and biodiesel. Thus, African countries are encouraged to invest in the cultivation of this potentially rich plant in order to reduce over-dependence on the currently limited sources of protein and oil.

The search for alternative sources of energy to supplement or replace fossil fuels so as to fetch their increasing demands, uncertain availability and to reduce the associated pollution problems of their combustion has drawn attention towards fuels of biological origin (Marchenko and Semenov, 2001), which provides a regenerable feedstock. As the plant is undergoing development in its various utilisation potentials, it is pertinent that factors that facilitate its large production such as soil nutrient and age of plant be investigated. Thus, this study tends to determine the influence of different rates of $N$ and $P$ fertilizers on the vegetative growth and the effect of years of establishment on the yield of Thevetia peruviana.

\section{Study area}

\section{MATERIALS AND METHODS}

The research work was carried out at the Research Farm of the Bio-fuel and Alternate Renewable Energy Ltd, Edidi, Kwara State in the southern Guinea savannah of Nigeria between June 2009 and June 2012.

\section{Soil sampling}

Pre-cropping soil samples were randomly taken from six spots using the soil auger at $0-30 \mathrm{~cm}$ soil depth from the experimental field. The samples collected were bulked to obtain composite sample for routine soil analysis in the laboratory to determine physico-chemical properties of the experimental site.

\section{Sampling design}

The experiment was laid out in a RCBD in a factorial arrangement with three replications. The factors includes: 3 levels of $\mathrm{N}\left(0,30\right.$ and $\left.60 \mathrm{~kg} \mathrm{ha}^{-1}\right)$ and 3 levels of $P\left(0,30\right.$ and $\left.60 \mathrm{~kg} \mathrm{ha}^{-1}\right)$ which were combined factorially. 


\section{Planting technique}

The land was ploughed once and harrowed twice to give a well pulverized soil. The size of each plot in the experiment was $10.0 \mathrm{~m} \times 4.0 \mathrm{~m}$. The plants were transplanted at $2.0 \mathrm{~m}$ by $2.0 \mathrm{~m}$ spacing to give a total population of 10 plants per plot. There were nine plots in each of the replicate giving a total population of 90 plants per replicate. Mature seeds were manually picked under a five year old plant after which it was cleaned, sorted for viability and pre-germinated in plastic bags for 6 weeks before they were transplanted on a flat field at a spacing of $2 \mathrm{~m}$ by 2 meters with a plant population of 2,500 plants ha-1.

\section{Fertilizer application}

Nitrogen fertilizer in form of Urea (46\% N) was applied at the rate of $0 \mathrm{~kg} \mathrm{~N} \mathrm{ha}^{-1}, 30 \mathrm{~kg} \mathrm{~N}^{-1}$ and $60 \mathrm{~kg} \mathrm{~N}^{-1}$ while phosphorus fertilizer in the form of single superphosphate (18\% $\left.\mathrm{P}\right)$ was applied at the rate of $0 \mathrm{kgP}_{2} \mathrm{O}_{5} \mathrm{ha}^{-1}, 30 \mathrm{kgP}_{2} \mathrm{O}_{5} \mathrm{ha}^{-1}$ and $60 \mathrm{kgP}_{2} \mathrm{O}_{5} \mathrm{ha}^{-1}$. Phosphorus fertilizer was applied once at transplanting while nitrogen fertilizer was applied in two split doses, the first half of nitrogen was applied at 2 weeks after transplanting (WAT) while the second half was applied at 6 weeks after transplanting. Fertilizer application was done only in the first year of the experiment.

\section{Harvesting}

The first, second and third year harvests were terminated when the plants were exactly one, two and three years old respectively.

\section{Herbicide Application}

In the first and second year of the experiment, glyphosate was used at the rate of $2.5 \mathrm{~kg} \mathrm{a.i} \mathrm{ha-1}$ to control both annual and perennial weeds at intervals of ten and fifteen weeks respectively while in the third year, the canopy was fully covered to naturally control weeds.

\section{Data collection and analysis}

Vegetative growth parameters- plant height, number of primary branches, stem girth were determined at 8, 16 and 24 WAT and number of days to first and 50\% flower appearance were taken only in the first year of the experiment while the yield parameters- number of harvested seeds and weight of harvested seeds were taken at both the first, second and third year of the experiment. The data collected was subjected to analysis of variance (ANOVA) using Statistical Analysis Software (SAS) and the significant means were separated using the Least Significant Difference (LSD) at $5 \%$ level of probability $(p \leq 0.05)$.

\section{RESULTS}

The pre-cropping soil sample characteristics indicated that the soil of the experimental site was sandy loam that was moderately acidic (Table 1). The organic matter and total nitrogen were moderate while the phosphorus level was low. 
Aboyeji \& Babalola, 2013

Table 1: Physico-Chemical properties of the soil of the experimental sites during 2009 and 2011 rainy seasons.

\begin{tabular}{|c|c|c|}
\hline \multirow[b]{2}{*}{ Soil characteristics } & \multicolumn{2}{|c|}{ Soil Depth } \\
\hline & $\begin{array}{c}2009 \\
0-30 \mathrm{~cm}\end{array}$ & $\begin{array}{c}2011 \\
0-30 \mathrm{~cm}\end{array}$ \\
\hline \multicolumn{3}{|l|}{ Physical characteristics \% } \\
\hline Clay & 236 & 236 \\
\hline Silt & 40 & 80 \\
\hline Sand & 724 & 684 \\
\hline Textural class & Sandy loam & Sandy loam \\
\hline \multicolumn{3}{|l|}{ Chemical characteristics } \\
\hline pH1:1 in $\mathrm{H}_{2} \mathrm{O}$ & 6.20 & 5.60 \\
\hline Organic Carbon g/kg & 1.51 & 1.10 \\
\hline Organic matter g/kg & 2.82 & 2.30 \\
\hline Total Nitrogen $\mathrm{g} / \mathrm{kg}$ & 2.15 & 1.62 \\
\hline Available Phosphorus m/kg & 1.48 & 1.12 \\
\hline \multicolumn{3}{|c|}{ Exchangeable bases $\left(\mathrm{cmol} \mathrm{kg}^{-1}\right)$} \\
\hline$\overline{\mathrm{K}}$ & 1.44 & 1.43 \\
\hline $\mathrm{Na}$ & 1.92 & 1.63 \\
\hline $\mathrm{Ca}$ & 0.90 & 0.68 \\
\hline $\mathrm{Mg}$ & 0.36 & 0.32 \\
\hline CEC & 4.62 & 4.06 \\
\hline
\end{tabular}

Nitrogen rates significantly affected the height of T.peruviana except at 8 WAT whereas plant height was significantly influenced by the levels of phosphorus fertilizer except at 8 WAT (Table 2). Where significant differences were observed, plots with no nitrogen fertilizer had significantly tall plants compared to plots where $60 \mathrm{~kg} \mathrm{~N}^{-1}$ was applied. Significantly taller plants were observed on plots that had 30 and $60 \mathrm{~kg} \mathrm{P}$ ha-1 $^{-1}$ compared plots with no phosphorus fertilizer.

Table 2: Effect of rates of nitrogen and phosphorus fertilizers on plant height $(\mathrm{cm})$ of Thevetia peruviana.

\begin{tabular}{|c|c|c|c|}
\hline \multirow[t]{2}{*}{ Treatment } & \multicolumn{3}{|c|}{ Sampling Periods (WAT) } \\
\hline & 8 & 16 & 24 \\
\hline \multicolumn{4}{|c|}{ Nitrogen $(\mathrm{N})$ rate $\mathrm{Kgha}^{-1}$} \\
\hline 0 & 42.47 & $74.73 a$ & $93.98 a$ \\
\hline 30 & 41.38 & 72.36ab & $90.38 a b$ \\
\hline 60 & 40.93 & $70.00 \mathrm{~b}$ & $87.40 \mathrm{~b}$ \\
\hline $\operatorname{LSD}(0.05)$ & N.S & 3.79 & 5.73 \\
\hline \multicolumn{4}{|c|}{ Phosphorus $(\mathrm{P})$ rate $\mathrm{Kgha}^{-1}$} \\
\hline 0 & $40.13 b$ & 71.40 & 89.49 \\
\hline 30 & $41.12 \mathrm{a}$ & 72.04 & 90.07 \\
\hline 60 & $43.52 a$ & 73.64 & 92.07 \\
\hline $\operatorname{LSD}(0.05)$ & 2.93 & N.S & N.S \\
\hline \multicolumn{4}{|l|}{ Interaction } \\
\hline $\mathrm{N}^{*} \mathrm{P}$ & N.S & N.S & N.S \\
\hline
\end{tabular}


Aboyeji \& Babalola, 2013

Means in a column under any given treatment followed by the same letter(s) do not differ significantly at 0.05 level of probability using the Least Significant Difference (LSD).

N.S $=$ Not significant

The number of primary branches significantly decrease and increase gradually with an increased in application of nitrogen and phosphorus fertilizers respectively (Table 3).

Table 3: Effect of Rates of Nitrogen and Phosphorus Fertilizers on Number of Primary Branches of Thevetia peruviana.

\begin{tabular}{|c|c|c|c|}
\hline \multirow[t]{2}{*}{ Treatment } & \multicolumn{3}{|c|}{ Sampling Periods (WAT) } \\
\hline & 8 & 16 & 24 \\
\hline \multicolumn{4}{|c|}{ Nitrogen $(\mathrm{N})$ rate $\mathrm{Kgha}^{-1}$} \\
\hline 0 & $10.47 a$ & $25.47 a$ & $33.04 a$ \\
\hline 30 & $10.04 a$ & $25.80 a$ & $32.82 a$ \\
\hline 60 & $8.24 b$ & $22.87 \mathrm{~b}$ & $29.20 \mathrm{~b}$ \\
\hline $\operatorname{LSD}(0.05)$ & 1.29 & 2.54 & 3.20 \\
\hline \multicolumn{4}{|c|}{ Phosphorus $(\mathrm{P})$ rate Kgha-1 } \\
\hline 0 & $8.87 \mathrm{~b}$ & $22.76 \mathrm{~b}$ & $29.67 \mathrm{~b}$ \\
\hline 30 & $9.93 a b$ & $24.67 \mathrm{~b}$ & $31.80 \mathrm{~b}$ \\
\hline 60 & $10.69 a$ & $27.71 \mathrm{a}$ & $35.60 \mathrm{a}$ \\
\hline $\operatorname{LSD}(0.05)$ & 1.29 & 2.54 & 3.20 \\
\hline \multicolumn{4}{|l|}{ Interaction } \\
\hline $\bar{N}^{*} P$ & N.S & N.S & N.S \\
\hline
\end{tabular}

Means in a column under any given treatment followed by the same letter(s) do not differ significantly at 0.05 level of probability using the Least Significant Difference (LSD).

N.S $=$ Not significant

While the stem girth was not affected by application of nitrogen and phosphorus fertilizers except phosphorus at 8 WAT (Table 4), the Interaction between nitrogen and phosphorus fertilizers was significant at 8 WAT. Plots with no application of phosphorus fertilizer had significantly lower stem girth and this plots were similar to plots that $0 \mathrm{~kg} \mathrm{P} \mathrm{ha}^{-1}$ were combined with $60 \mathrm{~kg} \mathrm{~N} \mathrm{ha}^{-1}$. Other plots had relatively similar stem girth (Table 5) 
Aboyeji \& Babalola, 2013

Table 4: Effect of Rates of Nitrogen and Phosphorus Fertilizers on Stem Girth (cm) of Thevetia peruviana.

\begin{tabular}{|c|c|c|c|}
\hline \multirow[t]{2}{*}{ Treatment } & \multicolumn{3}{|c|}{ Sampling Periods (WAT) } \\
\hline & 8 & 16 & 24 \\
\hline \multicolumn{4}{|c|}{ Nitrogen (N) rate Kgha-1 } \\
\hline 0 & 0.97 & 1.78 & 2.11 \\
\hline 30 & 0.99 & 1.81 & 2.09 \\
\hline 60 & 0.93 & 1.71 & 1.97 \\
\hline $\operatorname{LSD}(0.05)$ & N.S & N.S & N.S \\
\hline \multicolumn{4}{|c|}{ Phosphorus $(\mathrm{P})$ rate Kgha-1 } \\
\hline 0 & $0.90 \mathrm{~b}$ & 1.78 & 2.09 \\
\hline 30 & $1.02 \mathrm{a}$ & 1.79 & 2.08 \\
\hline 60 & $0.98 a$ & 1.73 & 2.01 \\
\hline LSD (0.05) & 0.02 & N.S & N.S \\
\hline \multicolumn{4}{|l|}{ Interaction } \\
\hline $\bar{N}^{*} \mathrm{P}$ & * & N.S & N.S \\
\hline
\end{tabular}

Means within a column followed by the same letter do not differ significantly at 0.05 level of probability according to Duncan Multiple Range Test (DMRT)

$\begin{array}{lll}* & = & \text { Significant at } 5 \% \text { level of probability } \\ \text { N.S } & =\quad \text { Not significant }\end{array}$

Table 5: Interaction of Rates of Nitrogen and Phosphorus Fertilizers on Stem Girth of Thevetia peruviana at 8 WAT.

\begin{tabular}{clll}
\hline & $\mathbf{0}$ & Phosphorus fertilizer rates & $\mathbf{3 0}$ \\
\hline Nitrogen fertilizer rates & & $\mathbf{6 0}$ \\
0 & $0.83 \mathrm{e}$ & $1.02 \mathrm{a}-\mathrm{c}$ & $1.04 \mathrm{ab}$ \\
30 & $0.97 \mathrm{a}-\mathrm{d}$ & $1.05 \mathrm{a}$ & $0.94 \mathrm{~b}-\mathrm{d}$ \\
60 & $0.90 \mathrm{de}$ & $0.98 \mathrm{a}-\mathrm{d}$ & $0.92 \mathrm{c}-\mathrm{e}$ \\
$\operatorname{LSD}(0.05)$ & & 0.02 & \\
\hline
\end{tabular}

Means followed by the same letter (s) do not differ statistically at 0.05 level of probability according to Duncan Multiple Range Test (DMRT). $\quad$ N.S =Not significant.

Increase in $\mathrm{N}$ level from 30 to $60 \mathrm{~kg} \mathrm{~N} /$ ha significantly increased days to first and $50 \%$ flowering of $T$. Peruviana whereas application of $P$ significantly reduced days to first and $50 \%$ flowering of T. Peruviana (Table 6). 
Table 6: Effects of rates of nitrogen and phosphorus fertilizers on number of days to first and $50 \%$ flowering of Thevetia peruviana

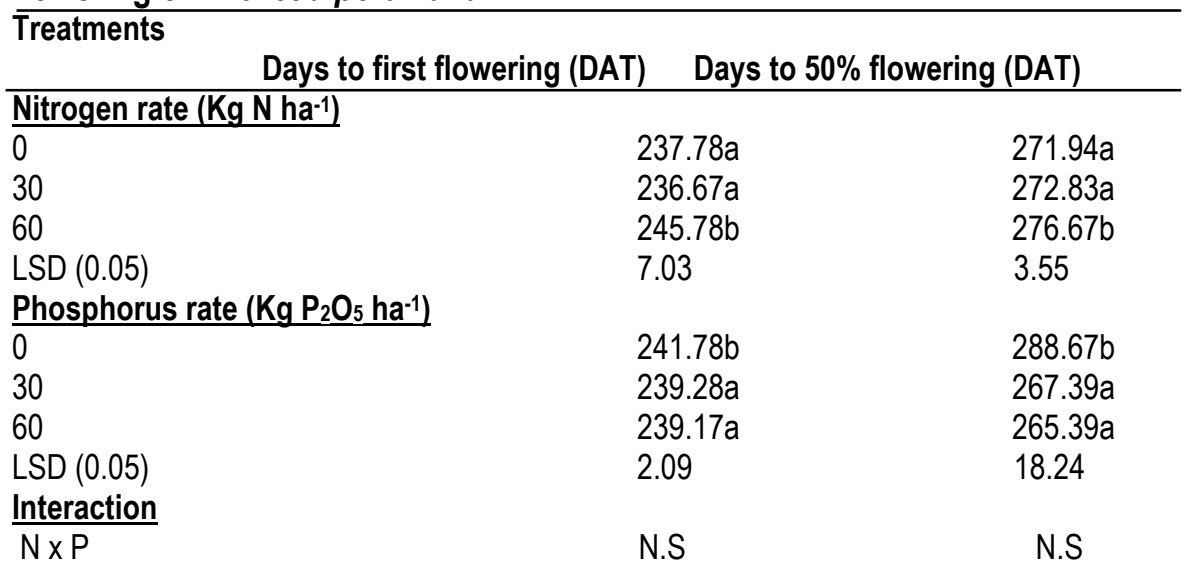

Means in a column under any given treatment followed by the same letter(s) do not differ significantly at 0.05 level of probability using the Least Significant Difference (LSD). N.S $=\quad$ Not significant

DAT= Days after transplanting

Application of 0 and $30 \mathrm{~kg} \mathrm{~N} \mathrm{a}^{-1}$ significantly increased both the number and weight of harvested seeds while application of 30 and $60 \mathrm{~kg} \mathrm{P}_{2} \mathrm{O}_{5}$ ha-1 $^{-1}$ gave a significantly higher number and weight of harvested seeds which was statistically similar (Tables 7 and 8 ).

Table 7: Effect of rates of nitrogen and phosphorus fertilizers on number of harvested mature seeds per plot (ha-1) of Thevetia peruviana

\begin{tabular}{|c|c|c|c|}
\hline \multirow[t]{2}{*}{ Treatment } & \multicolumn{2}{|c|}{ Number of Harvested Seeds } & \multirow[b]{2}{*}{ 3years old } \\
\hline & 1 year old & 2 years old & \\
\hline \multicolumn{4}{|l|}{ Nitrogen $(\mathrm{N})$ rate $\mathrm{Kgha}^{-1}$} \\
\hline 0 & $5,000 \mathrm{a}$ & $36,500 a$ & $370,450 a$ \\
\hline 30 & $3,444 b$ & $35,500 a$ & $371,650 a$ \\
\hline 60 & $2,944 b$ & $29,750 b$ & $306,800 b$ \\
\hline $\operatorname{LSD}(0.05)$ & 660.65 & 5,000 & 63,585 \\
\hline \multicolumn{4}{|c|}{ Phosphorus $(\mathrm{P})$ rate Kgha- ${ }^{-1}$} \\
\hline 0 & $1,972 b$ & $30,750 \mathrm{~b}$ & $317,675 b$ \\
\hline 30 & $3,722 a$ & $37,250 a$ & $386,175 a$ \\
\hline 60 & $4,294 a$ & $35,900 a$ & $381,975 a$ \\
\hline $\operatorname{LSD}\left(\begin{array}{ll}0 & .05\end{array}\right)$ & 660.65 & 5,000 & 63,585 \\
\hline \multicolumn{4}{|l|}{ Interaction } \\
\hline $\mathrm{N}^{*} \mathrm{P}$ & N.S & N.S & N.S \\
\hline
\end{tabular}

Means in a column under any given treatment followed by the same letter(s) do not differ significantly at 0.05 level of probability using the Least Significant Difference (LSD)

$$
\text { N.S = Not significant }
$$


Table 8: Effect of rates of nitrogen and phosphorus fertilizers on weight of harvested mature seeds per plot $\left(\mathrm{kg} \mathrm{ha}^{-1}\right)$ of Thevetia peruviana

\begin{tabular}{|c|c|c|c|}
\hline \multirow[t]{2}{*}{ Treatment } & \multicolumn{2}{|c|}{ Weight of Harvested Seeds } & \multirow[b]{2}{*}{ 3years old } \\
\hline & 1 year old & 2 years old & \\
\hline \multicolumn{4}{|c|}{ Nitrogen $(\mathrm{N})$ rate $\mathrm{Kgha}^{-1}$} \\
\hline 0 & $22.07 a$ & $1,094 a$ & $11,103.35 a$ \\
\hline 30 & $20.88 a$ & $1,195 a$ & $12,510.47 a$ \\
\hline 60 & $12.20 \mathrm{~b}$ & $898 \mathrm{~b}$ & $9,260.72 b$ \\
\hline LSD & 8.50 & 191.0 & 2,429 \\
\hline \multicolumn{4}{|c|}{ Phosphorus $(\mathrm{P})$ rate Kgha-1 } \\
\hline 0 & $10.04 b$ & $923 b$ & $9,035.42 b$ \\
\hline 30 & $21.22 \mathrm{a}$ & $1,115 a$ & $11,559.33 a$ \\
\hline 60 & $23.88 \mathrm{a}$ & $1,223 a$ & $13,012.69 a$ \\
\hline LSD & 8.50 & 191.0 & 2,429 \\
\hline \multicolumn{4}{|l|}{ Interaction } \\
\hline $\mathrm{N}^{*} \mathrm{P}$ & N.S & N.S & N.S \\
\hline
\end{tabular}

Means in a column under any given treatment followed by the same letter(s) do not differ significantly at 0.05 level of probability using the Least Significant Difference (LSD)

N.S = Not significant

\section{DISCUSSION}

The result obtained from this study revealed that application of $60 \mathrm{~kg} \mathrm{~N}^{-1}$ significantly reduced plant height and number of primary branches of $T$ peruviana while plots with no $\mathrm{N}$ had significantly higher plant height and number of branches. This means that $2.15 \mathrm{~N} \mathrm{~g} / \mathrm{kg}$ obtained from the pre-cultivation soil analysis was sufficient to aid the growth of the plants and the reduction in growth as the nitrogen level increases could be attributed to the burning effect of excess nitrogen fertilizer on plants.

Youssefi et al. (2000) reported that trees appear to have a finite capacity to use available soil $\mathrm{N}$ and demonstrate the capacity to self-regulate net $\mathrm{N}$ uptake once that capacity has been met. The yield of $T$. Peruviana from this experiment was also observed to be suppressed with increasing nitrogen fertilizer. This could be as a result of reduction in the vegetative growth of the plant at the early stage of development. Achten et al., (2008) observed that optimal fertilization can increase the seed and oil yield, but high fertilization can result in low seed production.

Application of phosphorus fertilizer increased both plant height and number of primary branches. This result indicated that phosphorus is essential for the general health and vigour of thevetia plants and the effect of phosphorus on growth have been reported in several investigations. Das et al. (1991) found an increase in black cumin (Nigella sativa) height, number of branches and fresh weight and dry weight of shoots and roots with increasing phosphorus concentration from 20 to $40 \mathrm{~kg} / \mathrm{ha}$. This was also supported by Munshi et al. (1990) who reported an increase in plant height and number of branches of Carum carvi grown from root tubers when phosphorus 
was applied at the rate of $40 \mathrm{~kg} / \mathrm{ha}$. Rathore et al., (1992) also observed that adequate amount of phosphorus in soils favours rapid plant growth, early fruiting / maturity and improve the quality of the produce.

The results of this study also reveal that application of phosphorus fertilizer significantly increased the yield (number and weight of harvested seeds). This showed that phosphorus fertilizer improved seed production. Scheffel, (1999) documented that some specific growth factors that have been associated with phosphorus are: stimulated root development, increased stalk and stem strength, improved flower formation and seed production.

\section{CONCLUSSION}

The result of this study suggests that, the native $\mathrm{N}(2.15 \mathrm{~N} \mathrm{~g} / \mathrm{kg})$ in the soil and application of 30 $\mathrm{kg} \mathrm{P}_{2} \mathrm{O}_{5}$ ha $^{-1}$ was enough to improve both the vegetative and yield performance of the plant in the study area in all the affected years.

\section{REFERENCES}

Achten, W. M. J., Verchot, L., Franken, Y. J., Mathijs, E., Singh, V. P., Aerts, R., and Muys, B., (2008). Jatropha bio-diesel production and use. Journal of Biomass Bioenergy, 32: 1063-1084.

Atteh, J. O., Ibiyemi, S. A. And Ojo, A. O., (1995). Response of broilers to dietary level of must in nthepar Thevetia cake, J. Agric. Sci., 125: 307 - 310.

Balusamy, T. and Manrappan, R. (2007). Performance evaluation of direct injection diesel engine with blends of Thevetia peruviana seed oil and diesel. J. Sci. Industrial Res., 66: 1035-1040.

Daniel, J. M., (1937). The useful plant of West Africa. Lord. Oxford University Press. 2: 210-212

Das, A. K., Sadhu, M. K., and Som, M.G., (1991). Effect of N and P levels on growth and yield of black cumin (Nigella sativa L.) Hort. J., 4: 41-7

Ibiyemi, S. A, Fadipe, V. O., Akinremi, O. O., and Bako, S. S., (2002). Variation in oil composition of Thevetia peruviana juss fruits seeds. J Appl. Sci. Environ Management 6 (2): 61-65

Ibiyemi, S. A, Bako, S. S Ojokuku, G. O and Fadipe, V. O (1995). Thermal stability of Thevetia peruviana juss seed oil. J. Am. Oil Chem. Soc. 72 (6) 745-747

Marchenko, A. P. and Semenov, V. G. (2001). Alternative biofuel from rape oil derivative. Chem. Technol. Fuels Oils, 37(3): 183-185.

Munshi, A. M, Zargra, G. H., Baba, G. H. and Bhat, G.N. (1990). Effect of fertilizer levels on black zeera (Carum carvi) grown from root tubers. Indian Cocoa, Arecanut and Spices J., 13: 134-6

Oluwaniyi, O. O, Ibiyemi S. A and Usman A. L., (2007). Effect of detoxification on the nutrient content of $T$. peruviana seed cake. Res. J. of Applied Sci. 2(2): 188-191.

Rathore, R. S., Khandwe, R., Khandwe, N. and Singh, P. P. (1992). Effect of irrigation schedules, phosphorus levels and phosphate solublizing organism on lentil yield. Lens, 19:17-19.

Scheffel, L. R., (1999). Nutrient Facts (Quick Nutrient Guide Handbook). New York: Brooks Printing Company. 2:70-71 
Aboyeji \& Babalola, 2013

Usman, L. A., Oluwaniyi, O. O., Ibiyemi, S. A., Muhammad, N. O. and Ameen, O. M., (2009). The potential of Oleander (Thevetia peruviana) in African agricultural and industrial development: a case study of Nigeria. Journal of Applied Biosciences 24: 1477 - 1487

Youssefi, F., Weinbaum, S. A., and Brown, P.H., (2000). Regulation of nitrogen partitioning in field-grown almond trees: Conference Proce (2) of fruit load and foliar nitrogen applications. Plant Soil 227:273-281. 